\title{
RETINAL COMPLICATIONS IN DIABETES MELLITUS: IMPORTANCE OF SCREENING AND MANAGEMENT
}

\section{Milena Golubovik}

University Clinic of Eye Diseases, Medical Faculty, Ss. Cyril and Methodius University, Skopje, R. Macedonia

Corresponding Author: Milena Golubovik, University Clinic of Eye Diseases, Medical Faculty, Ss. Cyril and Methodius University, Skopje, R. Macedonia, Tel: +389 (0)2 783694 19, E-mail: golubovicarsovska@yahoo.com

\begin{abstract}
Introduction: Diabetic retinal complications are the most common cause of reduced visual acuity in persons aged 25 to 75 years. However, vision loss can be prevented or delayed if the changes are seen on time.

Aim: By analyzing literature data to create an algorithm for careful follow-up of diabetic patients, which would prevent progression of the changes and development of conditions leading to blindness. At the same time, this paper presents certain changes of the eye fundus and mode of their treatment. Material and method: Analysis of studies published on diabetic retinopathy and screening conducted in developed countries, with creating an algorithm for follow-up of diabetic retinal changes and their management.

Conclusion: Timely detection and treatment of diabetic retinopathy with application of protocols in developed countries as well as parallel correction of systemic risk factors for progression of diabetic retinopathy will reduce the possibility of visual impairment in diabetics due to retinal complications. At the same time expenditures related to more complicated and less effective surgical procedures will be reduced along with the societal concern.
\end{abstract}

Key words: diabetic retinopathy, screening, management.

Diabetes mellitus is a multifactorial, heterogenic, metabolic disorder characterized by chronic hyperglycemia and disturbances of carbohydrate, fat and protein metabolism as a result of defects in insulin secretion, insulin action or both [1].

Dysmetabolic syndrome present in diabetes mellitus causes blood vessels pathologic alterations, primarily in retinal microvasculature, resulting in damage of all organs of the human body with consequent disability. Late complications in diabetes mellitus include macrovascular (atherosclerosis and cardiovascular disease, cerebrovascular disease and disease of peripheral blood vessels) and microvascular (diabetic nephropathy, neuropathy and diabetic retinopathy) [2]. It is a well-known fact that perception of the external world is done through eyes in almost $80 \%$, and thus the importance of diabetic retinopathy is evident as one of the late complications in diabetic patients.

According to the Health Intelligence an estimated 382 million people had diabetes in 2013 and by 2030 this number is estimated to almost double, is a significant number [3]. At the same time diabetic retinal complications are the most common cause of reduced visual acuity in persons aged 25 to 75 years, that is, in the working-age and productive population. These facts about the nature of the disease and its incidence portray the implications not only 
on the personal health but on socio-economic status of the country, as well.

The large interest for the disease has been at the same time a provocation to conduct a large number of studies worldwide, some of them being collaborative, multicentered and long-lasting. The aim of these studies has been to resolve many unknown issues and they have presented knowledge on the development of diabetic retinopathy, risk factors and treatment of patients. Table 1 gives a list of some of the conducted studies.

Table 1

Some of the multicentered collaborative studies on diabetic retinopathy

Diabetic Retinopathy Study (DRS, 1976-1986)
The Wisconsin Epidemiologic Study of Diabetic Retinopathy (WESDR 1984-1994)
Early Treatment Diabetic Study (ETDRS,1985-1995)
Diabetic retinopathy Vitrectomy Study (DRVS, 1985-1990)
Diabetes Control and Complications Trial (DCCT, 1993-1995)
United Kingdom Prospecctive Diabetic Study (UKPDS, 1998)
Action to Control Cardiovascular Risk in Diabetes
(The ACCORD Eye study 2001 - not finished)
Data from an Epidemiological Study on the Insulin Resistance syndrome Study
(The French DESIR study 1994/96-2004/6)
Diabetic Retinopathy Clinical Research Network treatment protocol for the Center-
involved Diabetic macular Edema ((2011)

Table 2

Levels of diabetic retinopathy

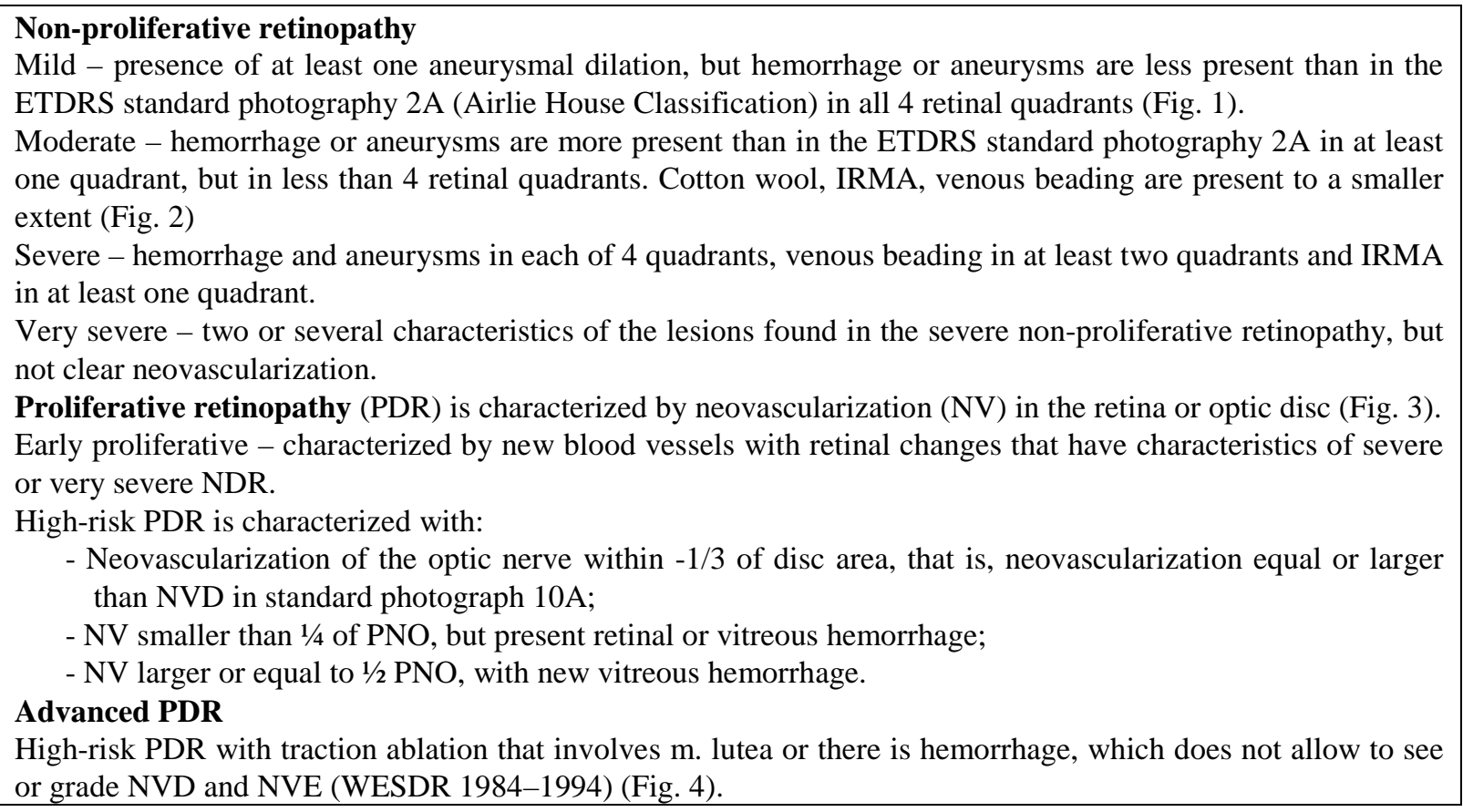

ETDR Study Report No 12. (taken from: Aiello L.M et al. 1999)

Studies have shown that adequate treatment, that is application of scatter panretinal Laser Photocoagulation (LFC), reduces the risk of vision loss within 5 years in patients whose stage of retinopathy is advancing to high-risk proliferative retinopathy of 5\% (which usually amounts to $60 \%$ ) while in patients with Clinically Significant Macular Oedema (CSMO) it reduces the risk of moderate vision loss from $50 \%$ to $12 \%$, and even to a smaller percentage if focal LFC to macula is applied [4]. 
Understanding the mechanisms, risk factors for development of vascular changes and their characteristics have yielded classification of stages of diabetic retinopathy. The percentage of progression from the current stage to the advanced stage within one year as well as progression to high-risk proliferative retinopathy has also been demonstrated.

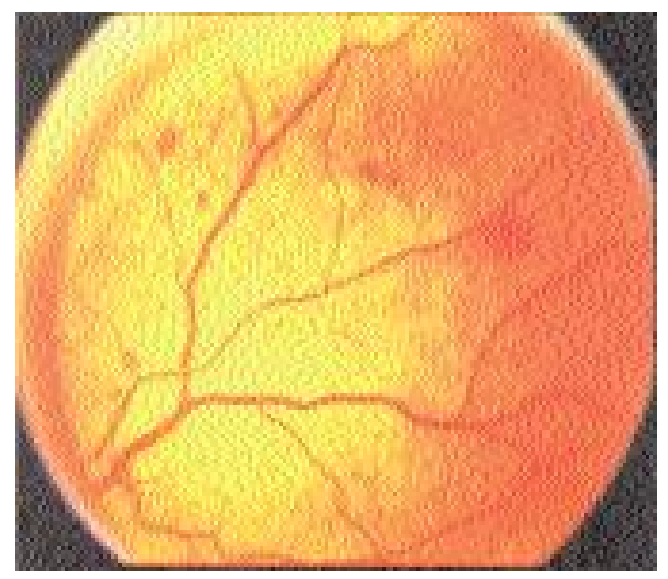

Figure 1-Airlie House standard photo $2 \mathrm{~A}$

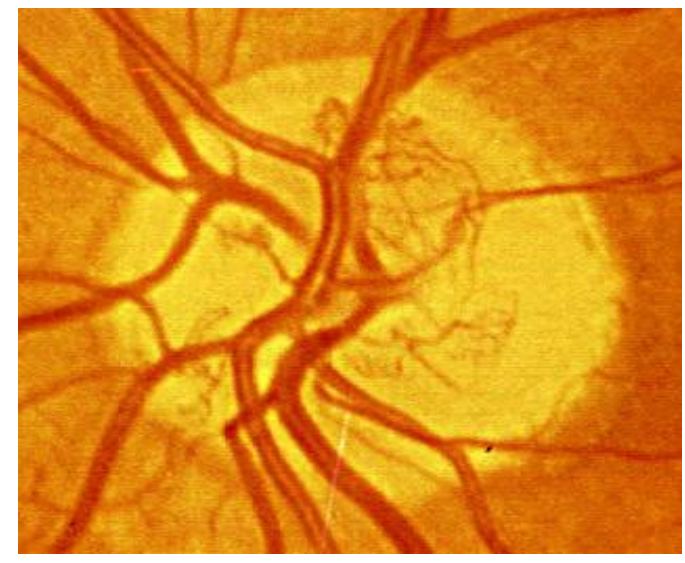

Figure 3 - Airlie House standard photo $10 \mathrm{~A}$

Maculopathy is a separate entity of diabetic retinal impairment and it can occur in all stages of diabetic retinopathy (Fig. 5). It can be manifested as retinal edema (seen as retinal thickening within 2 disc diameters -2 DD of the center of the macula). Edema that involves the center of the macula should be treated and is separately denoted as a clinically significant macular edema (CSME; ETDRS). Besides edema, during development of diabetic retinal changes macula might suffer as a result of non-perfusion, traction in macula with fibrous tissue, lamellar or entire macular hole [4].
Table 2 presents the classification of the level of diabetic retinopathy according to Early Treatment Diabetic Retinopathy Study (ETDRS) (1991) scale that incorporates grading of diabetic retinopathy established by Airlie House classification, which has been made to serve the aims of the study. Retinopathy is generally divided into proliferative and non-proliferative $[4,5]$.

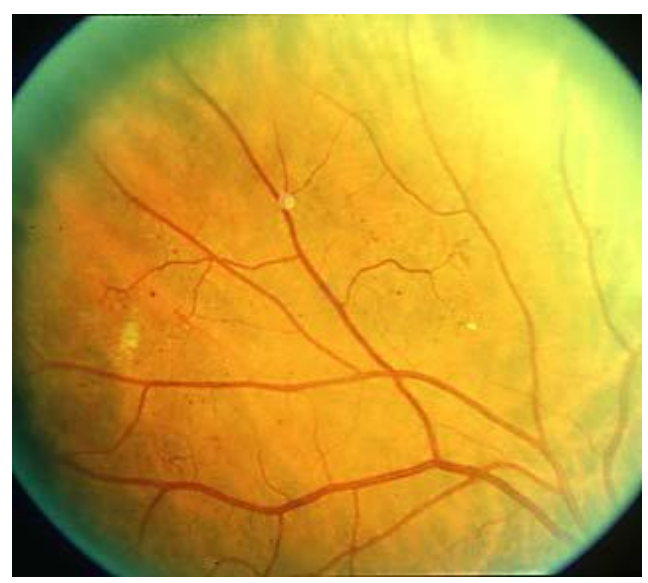

Figure 2-Airlie House standard photo $8 A$

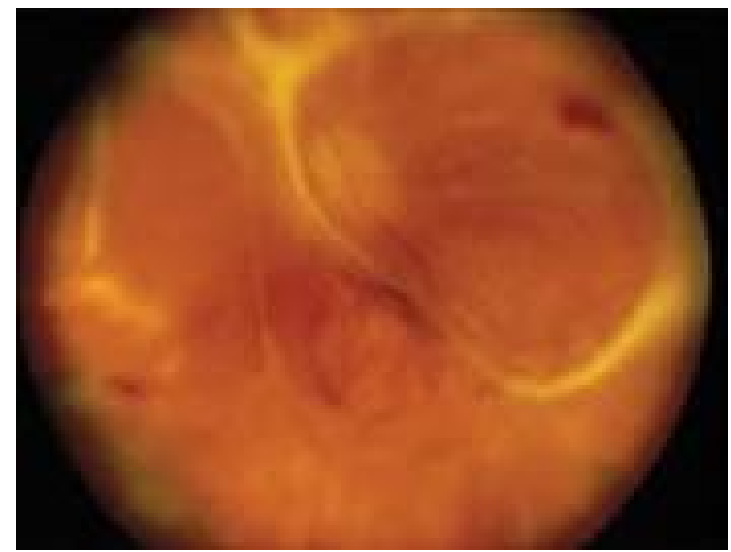

Figure 4-Advanced diabetic retinopathy

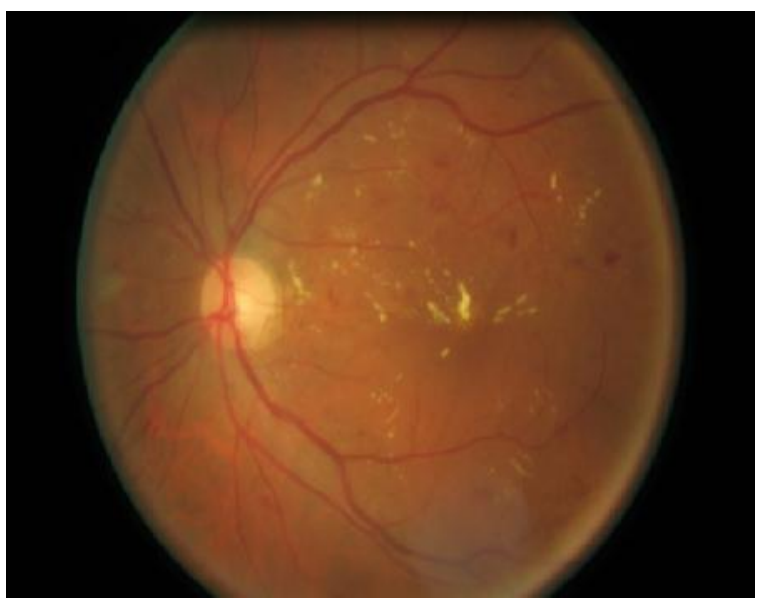

Figure 5-Diabetic maculopathy (CSME) 
Studies have also reported a very important issue related to degree of retinal changes progression indicating the timing of patient's follow-up. In fact, the following has been demonstrated:

- Mild: the risk of progression from non Proliferative Diabetic Retinopathy (NDR) to Proliferative Diabetic Retiniopathy (PDR) within one year is $5 \%$ while the risk of progression to high-risk PDR within five years amounts to $15 \%$.

- Moderate: the risk of progression to PDR within one year is $12-27 \%$ while in highrisk PDE within 5 years it amounts to $33 \%$.

- Severe: the risk of progression to PDR within one year is $52 \%$ while in high-risk PDR within 5 years it amounts to $60 \%$.

- Very severe: the risk of developing proliferative retinopathy within one year is $75 \%$.

As a result of the assessment of the risk progression ETDRS study proposed careful follow-up and advice for LFC treatment.

- Control of patients with mild or moderate diabetic retinopathy is advised at 6-12 months;

- Control of patients with severe diabetic retinopathy is advised at $2-4$ months;

- Control of patients with very severe diabetic retinopathy is advised at 2-3 months;

- In case of CSME in any form of retinopathy focal treatment of macula is recommended.

Macular edema might be treated with some new modules, such as intravitreous application of corticosteroids, anti Vascular Endothelial Growth Factor (anti-VEGF), or vitrectomy.

Immediate scatter panretinal photocoagulation is recommended both in early proliferative retinopathy and in high-risk diabetic retinopathy. Depending on the risk assessment made by the ophthalmologist scatter panretinal photocoagulation might be applied in severe and very severe retinopathy $[5,6]$.

Diabetic retinopathy is a complication with a progressive course leading to vision loss, but however, it has to be stressed that diabetic retinopathy is a condition in which vision loss can be prevented or delayed if changes are timely detected and adequate treatment is provided.
Initial ophthalmological approach and timing of examination in diabetic patients

Since diabetic retinopathy is very often asymptomatic and hence suitable to be treated, systemic ophthalmic examinations are essential to ensure early detection.

\section{Important issues in diabetic patients!}

When establishing the diagnosis of the disease (diabetes mellitus) it should take:

- Comprehensive ophthalmic examination,

- standard fundus photography (camera of 30-degrees) through dilated pupils and analyses of images.

Being aware of the seriousness of this problem there is a screening program for diabetic retinopathy in developed countries. This screening includes ophthalmologic examination of diabetic patients by employing standard stereoscopic fundus photographic technique (with camera of 30-degrees) through dilated pupils and analyses of images by ophthalmologists - specialists in this field. It is under discussion whether one fundus image taken with camera of 45-degrees is valid for detecting the existence and grade of diabetic retinopathy. However, since the number of diabetic population is increasing, by calculating the costs, time for screening and competent staff, studies accomplished in developed countries have balanced the efficacy of the screening and the expenditures.

Concerning economic efficacy, the study conducted by British researchers [7] has shown that only $30 \%$ of type 2 diabetic patients are likely to develop some degree of diabetic retinopathy over time. Consequently, the anticipated annual examination in patients at no other risks might not be cost-effective. The mentioned study comprised 7600 patients with type 2 diabetes and analyzed the results of the annual eye examinations. The percentage of potentially sight-threatening disease ranged from $0.3 \%$ in patients with no initial evidence of retinopathy in the first year to $15 \%$ in patients with moderate diabetic retinopathy at their first examination of establishing the diagnosis.

In line with the conclusions of the study a regular ophthalmic examination has been recommended in diabetic patients who showed no signs of retinopathy at the initial examination. Annual ophthalmic examination has been 
advised to patients who started insulin treatment for diabetes or who have had the disease for more than 20 years or who have had sings of a background retinopathy. In case of mild retinopathy at initial examination follow-up is advised at each 4 months [7].

Respecting the recommendations of the previous studies, first of all of ETDRS, and based on clinical evidence presented in recent studies, together with the conclusions of American Diabetes Assotiation (ADA) and American Academy of Ophthalmology ( AAO) [8, 9, 10, 11, 14], National Health and Medical Research Council (NHMRC) [18], National Guideline Clearinghouse [13], NHS (National Health Screening) program $[15,16]$, etc. the following has to be remembered and it is sublimed in the presented algorithm of the Module 10 of Type 2 Diabetes Mellitus within Hong Kong Reference Framework for Diabetes Care for Adults [17, 18].

Algorithm of ophthalmological follow-up in diabetic patients

MODULE 10 (Hong Kong Reference Framework for Diabetes Care for Adults)

Appropriate follow-up care of the eyes:

1. Immediately upon detection of DM, it is necessary to make examination through dilated pupils and determine visual acuity, clouding of the eye's lens and onset of retinopathy;

2. Fundus photography;

3. Follow-up: once per year.

In case of one or several normal findings the follow-up is advised at 2-3 years. factors.

Examination of diabetic patients with risk
Control examinations are to be made more frequently if there is a background retinopathy in patients with the following risk factors:

- Poor glycemic control (HbA1c > 8\%);

- Poor blood pressure control;

- Sudden reduction of visual acuity;

- Duration of diabetes for more than 10 years;

- Microalbuminuria and proteinuria;

- Hyperlipidemia;

- Pregnancy.

4. When planning pregnancy, a comprehensive eye examination and counseling on the risk of development and progression of DR is recommended. During pregnancy eye examinations are to be made in the first trimester and possibly again throughout pregnancy and one year postpartum.

Need for referral to tertiary ophthalmological institution

A DM patient who has been found to have macular edema, pre-proliferative or proliferative retinopathy is referred to an experienced ophthalmologist, who is an expert in treatment of diabetic retinopathy.

In all cases of DM with the following conditions:

- Pregnancy;

- Proliferative or pre-proliferative retinopathy;

- Severe non-proliferative retinopathy that is sudden and progressive;

- Macular edema;

- Unexplained visual impairment.

Table 3

Gives a schematic presentation of Module 10

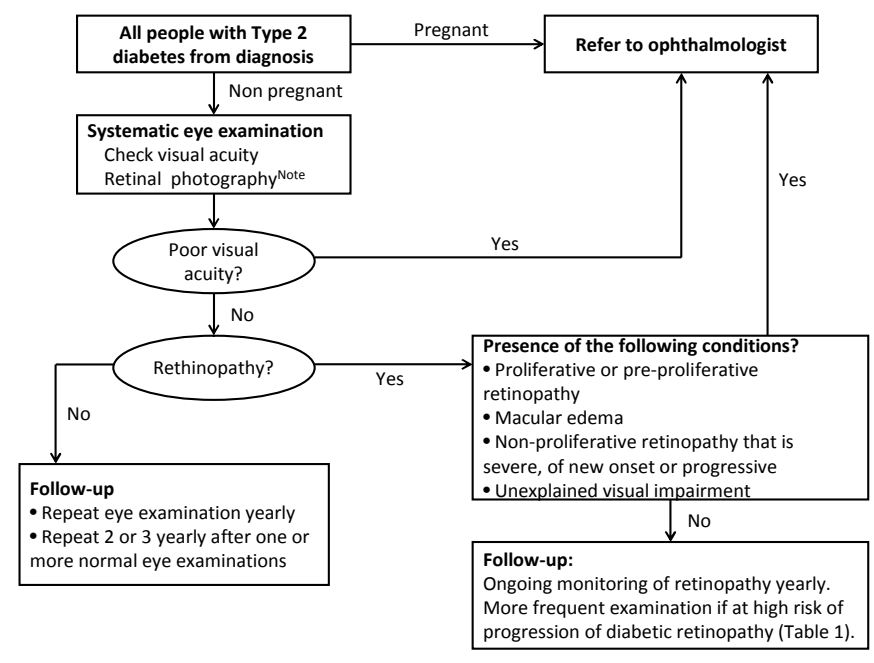


In type $1 \mathrm{DM}$ the first control is recommended at 3-5 years after diagnosis of the disease and consequently at 1 year. Evaluation for diabetic retinopathy is not necessary in children aged 10-11 years. During puberty a closer monitoring is recommended [9].

Diabetic retinal complications are still an important and current problem, which has been confirmed by the latest research implying the complexity of the retinal damage mechanisms $[19,20,21]$. However, development and application of new imaging technologies and new therapeutic modalities [22, 23, 24] offered new possibilities for treatment of retinal complications.

Vitreous surgery is reserved for more severe cases of diabetic retinopathy. However, early detection of retinal diabetic complications and their treatment will prevent and delay development of retinal complications, especially development of an advanced stage of diabetic retinopathy that cannot be managed and can lead to eye pain due to development of neovascular glaucoma. These conditions are to be recognized by the ophthalmologists if they comply with the principles of detection and treatment of diabetic retinal complications (Fig. 6).

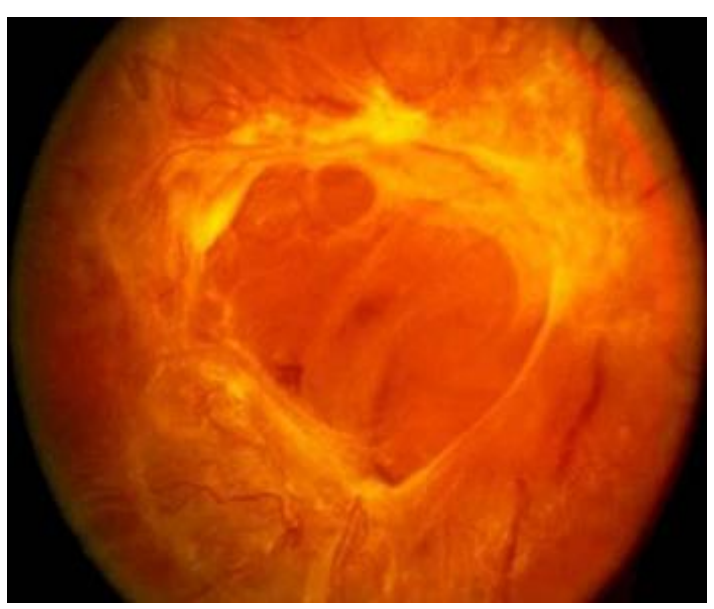

Figure 6-Advanced diabetic retinopathy with retinal glyosis

\section{Conclusion}

Timely detection and treatment of diabetic retinopathy with application of protocols in developed countries as well as parallel correction of systemic risk factors for progression of diabetic retinopathy will reduce the possibility of visual impairment in diabetic patients due to retinal complications. At the same time expenditures related to more complicated and less effective surgical procedures will be reduced along with societal concern.

\section{REFERENCES}

1. Bennett H, Knowler WC. Definition, Diagnosis and Classification of diabetes mellitus and glucose homeostasis. In: Khan R, Weir GC, King GL, Jacobson AM, Moses AC, Smith RJ editors. Joslin Diabetes Center. Boston: Lipincott Wiliams \& Wilkins; 2005, p. 105-13.

2. Diabetes Mellitus Complications. In: Larsen. Williams Textbook of Endocrinology. $10^{\text {th }}$ ed. 2003. Available from:

http://members.tripod.com/ enotes/dm_complicatio ns.htm

3. Health Intelligence: Analyzing health data, generating and communicating evidence to improve population health. Prevalence of Diabetes in the World, 2013 Available from:

http://healthintelligence.drupalgardens.com/content/ prevalence-diabetes-world-2013

4. Aiello LM et al. Diabetic retinopathy. In: Guyer, Yannuzzi, Chang, Shields, Green editors. RetinaVitreous-Macula. Philadelphia: WB Saunders Co, 1999. p. 316-44.

5. Wykoff CC, Brown DM. Medscape Ophthalmology: Diabetic Retinopathy: A Team Approach to Screening, Referral, and Treatment. Disclosures Mar 20, 2012. Available from:

http://www.medscape.com/viewarticle/760431

6. Chakrabarti R, Harper CA, Keefe E. Diabetic Retinopathy Management Guidelines. Expert Rev Ophthalmol. 2012; 7(5): 417-39. Available from: http://www.medscape.com/viewarticle/775150

7. Diabetes Health Center: Do Diabetics Need Yearly Eye Exams? Study: Once Every 3 Years May Be Enough for Some. Available from: http://diabetes.webmd.com/news/20030116/dodiabetics-need-yearly-eye-exams

8. American Academy of Ophthalmology: Preferred Practice Pattern Guidelines: Diabetic Retinopathy PPP - Updated Oct 2012. Available from: http://one.aao.org/CE/PracticeGuidelines/PPP_Conte nt.aspx?cid=d0c853d3-219f-487b-a524326ab3cecd9a

9. Fong DS, Aiello L, Gardner TW, King GL, Blankenship G, Cavallerano JD, et al. Diabetic Retinopathy. Available from:

http://care.diabetesjournals.org/content/26/suppl_1/s 99.full

10. Agardh E, Tababat-Khani P. Adopting 3-Year Screening Intervals for Sight-Threatening Retinal Vascular Lesions in Type 2 Diabetic Subjects without Retinopathy. Diabetes Care 2011; 34: 1318-9. Available from:

http://care.diabetesjournals.org/content/34/6/1318.fu 11.pdf 
11. Garg S, Davis RM. Diabetic Retinopathy Screening Update. ADA Clinical Diabetes. Available from: http://clinical.diabetesjournals.org/content/27/4/140.f ull

12. NHS Diabetic Eye Screening Programme: Clinical Guidelines. Available from: http://diabeticeye.screening.nhs.uk/clinicalguidelines

13. National Guideline Clearinghouse: Diabetic retinopathy. Available from: www.guideline.gov/content.aspx ?id=13502

14. Do Diabetics Need Yearly Eye Exams? Available from: http://diabetes.webmd.com/news/20030116/dodiabetics-need-yearly-eye-exams

15. The Royal College of Ophthalmologists: Diabetic Retinopathy Guidelines, Dec 2012 Available from: www.rcophth.ac.uk/core/core_picker/download.asp?i $\mathrm{d}=1533$

16. Granchi F. The Royal College of Ophthalmologists' Clinical Guidelines for Diabetic Retinopathy. Eye. 2013; 27(2): 285-287. Available from: http://www.medscape.com/viewarticle/781123

17. Mitchell P, Foran S. Guidelines for the Management of Diabetic Retinopathy. Prepared by the Australian Diabetes Society for the Department of Health and Ageing. Available from:

http://www.nhmrc.gov.au/_files_nhmrc/publications /attachments/di15.pdf

18. Module 10 Diabetic Eye Disease. Available from: http://www.pco.gov.hk/tc_chi/resource/files/professi onals_DM_Module10.pdf

19. Cell Mechanism Leading to Diabetic Blindness Identified. Available from: http://www.sciencedaily.com/releases/2010/02/1002 01102022.htm

20. New Molecule Implicated in Diabetes-Associated Blindness. Available from:

http://www.sciencedaily.com/releases/2009/11/0911 25151734.htm

21. Study Explains Why Diabetic Retinopathy Is Difficult to Treat. Available from: http://www.sciencedaily.com/releases/2013/10/13100 7094243.htm

22. Diabetic Retinopathy Clinical Research Network. A randomized trial comparing intravitreal triamcinolone acetonide and focal/grid photocoagulation for diabetic macular edema. Ophthalmology. Sep 2008; 115(9): 1447-9, 1449.e1-10.

23. Elman MJ, Aiello LP, Beck RW, Bressler NM, Bressler SB, Edwards AR, et al. Randomized trial evaluating ranibizumab plus prompt or deferred laser or triamcinolone plus prompt laser for diabetic macular edema. Ophthalmology. Jun 2010; 117(6): 10641077.e35.

24. Bhavsar AR, Grillone LR, McNamara TR, Gow JA, Hochberg AM, Pearson RK. Predicting response of vitreous hemorrhage after intravitreous injection of highly purified ovine hyaluronidase (Vitrase) in patients with diabetes. Invest Ophthalmol Vis Sci. Oct 2008; 49(10): 4219-25.

Резиме

\section{KAJ DIABETES MELLITUS: I MENAXMENT}

\section{илен олубовиќ}

Клиника за очни болести, Медицински факултет, Универзитет „Св. Кирил и Методиј“, Скопје, Р. Македонија

Voved: Di jabet i ni reti nal ni kompli kaci i se naj esta pri i na za namal uvawe na vi dnata ostri na kaj popul aci jata od 25 do 75 godi ni. No i sto taka, toa e sostojba pri $\{$ to gubew et o na vi dot mo e da se preveni ra il i zabavi dokol ku promeni te se f at at navreme.

Celta na trudot e preku anal iza na literaturni podatoci da se postavi al goritamna sl edewe na di jabet i ni te [ to bi preveni ral o progresi ja na promeni te i nastanuvawe na sostojbi [ to doveduvaat do re i si nepovr at no gubew e na vi dot. Voedno, vo trudot se prika' ani oddel ni sostojbi na promenite na $0 \sim$ noto dno i na i not na ni vni ot $t r$ et man.

$M$ at er i jal i met od:A nal i za na soznani jat a od studi i te sprovedeni vo razvi eni te zemji, za razvojot na di jabeti nat a reti nopat i ja i skri ni ng, so postavuvawe al gor i tam za sl edewe na di jabeti ni te reti nal ni promeni i na i n na dejst vuvawe.

Zakl u ok: N avr emeno ot kri vawe i tret man na di jabet i nat a r et i nopati ja so i mpl ementaci ja na protokol i vo razvi eni te zemji, so i st ovr emena kor ekci ja na si stemski te ri zi k-f aktori za progresi ja na di jabet i nata ret i nopati ja \}e ja namal i mo' nosta za namaI uvawe na vi dot kaj di jabeti ari te poradi retinal ni komplikacii. I sto taka, \}e gi namal i f i nansiskite tro\{ oci povrzani za pote\{kite i pomal ku ef i kasni operati vni proceduri, a ne bi trebal o da se zanemari i soci jal ni ot aspekt.

KI urni zborovi : di jabet i na ret i nopat i ja, skri ni ng, menaxment. 